\title{
The Effects of the Adenosine Receptor Antagonists on the Reverse of Cardiovascular Toxic Effects Induced by Citalopram In-Vivo Rat Model of Poisoning
}

\author{
Müjgan Büyükdeligöz, Nil Hocaoğlu, Kubilay Oransay, Yeşim Tunçok, Şule Kalkan
}

Department of Medical Pharmacology, Dokuz Eylül University Faculty of Medicine, İzmir, Turkey

Background: Citalopram is a selective serotonin reuptake inhibitor that requires routine cardiac monitoring to prevent a toxic dose. Prolongation of the QT interval has been observed in acute citalopram poisoning. Our previous experimental study showed that citalopram may be lead to QT prolongation by stimulating adenosine $\mathrm{A} 1$ receptors without affecting the release of adenosine.

Aims: We examined the effects of adenosine receptor antagonists in reversing the cardiovascular toxic effects induced by citalopram in rats.

Study Design: Animal experimentation.

Methods: Rats were divided into three groups randomly ( $\mathrm{n}=7$ for each group). Sodium cromoglycate ( 20 $\mathrm{mg} / \mathrm{kg}$ ) was administered to all rats to inhibit adenosine A3 receptor mast cell activation. Citalopram toxicity was achieved by citalopram infusion $(4 \mathrm{mg} / \mathrm{kg} / \mathrm{min})$ for 20 minutes. After citalopram infusion, in the control group (Group 1), rats were given an infusion of dextrose solution for 60 minutes. In treatment groups, the selective adenosine A1 antagonist DPCPX (Group 2, 8-cyclopentyl-1,3-dipropylxanthine, $20 \mu \mathrm{g} / \mathrm{kg} / \mathrm{min}$ ) or the selective A2a antagonist CSC (Group 3, 8-(3-chlorostyryl)caffeine, $24 \mu \mathrm{g} / \mathrm{kg} / \mathrm{min}$ ) was infused for 60 minutes. Mean arterial pressure (MAP), heart rate (HR), QRS duration and QT interval measurements were followed during the experiment period. Statistical analysis was performed by ANOVA followed by Tukey's multiple comparison tests.

Results: Citalopram infusion reduced MAP and HR and prolonged the QT interval. It did not cause any significant difference in QRS duration in any group. When compared to the control group, DPCPX after citalopram infusion shortened the prolongation of the QT interval after 40, 50 and 60 minutes $(\mathrm{p}<0.01)$. DPCPX infusion shortened the prolongation of the QT interval at 60 minutes compared with the CSC group $(p<0.05)$. CSC infusion shortened the prolongation of the QT at 60 minutes compared with the control group $(\mathrm{p}<0.05)$.

Conclusion: DPCPX improved QT interval prolongation in citalopram toxicity. The results of this study show that mechanism of cardiovascular toxicity induced by citalopram may be related adenosine A1 receptor stimulation. Adenosine A1 receptor antagonists may be used for the treatment of citalopram toxicity.

Keywords: Adenosine receptor antagonists, citalopram, cardiovascular toxicity, QT prolongation, rat

This study was presented as an oral presentation at the Turkish Pharmacology Society, $21^{\text {th }}$ National Congress of Pharmacology, $5^{\text {th }}$ Clinical Pharmacology Symposium and $4^{\text {th }}$ Clinical Toxicology Symposium, 19-22 October 2011, Eskişehir, Turkey.

Address for Correspondence: Dr. Şule Kalkan, Department of Medical Pharmacology, Dokuz Eylül University Faculty of Medicine, İzmir, Turkey

Phone: +90 2324123905 e-mail: sule.kalkan@deu.edu.tr

Received: 07.11.2014 Accepted: 13.01.2015 • DOI: 10.5152/balkanmedj.2015.15932

Available at www.balkanmedicaljournal.org 
The citalopram, a selective serotonin re-uptake inhibitor (SSRI) is widely prescribed for the treatment of depression, obsessive-compulsive disorder or panic disorder (1). SSRIs are the second most common cause of antidepressant poisonings. Citalopram is the only SSRI that needs routine cardiac monitoring to prevent overdose when compared other SSRIs like fluoxetine, fluvoxamine, paroxetine and sertraline. Electrocardiagraphic abnormalities, especially prolongation of the QT interval, have been observed in overdose or following treatment with citalopram (2-8).

Adenosine is an endogenous nucleoside that has wellknown negative inotropic, chronotropic and dromotropic effects via the stimulation of adenosine $A_{1}$ receptors (9-11). The vasodilator effect is mediated by stimulation of the adenosine $\mathrm{A}_{2}$ receptor $(12,13)$.

In an experimental study, Pousti et al. (14) indicated that the negative inotropic and chronotropic effects induced by citalopram can be explained by the inhibition of adenosine re-uptake or the activation of adenosine $\mathrm{A}_{1}$ receptors. Also, Oransay et al. (15) demonstrated that CSC infusion before citalopram administration did not prevent the reduction in MAP and HR, the prolongation of the QT interval or affect the QRS duration. However, DPCPX, a selective adenosine $\mathrm{A}_{1}$ receptor antagonist, administered before citalopram infusion, did not prevent the reduction of MAP and HR or the prolongation of the QRS duration, but significantly prevented the prolongation of QT the interval. Additionally, citalopram infusion did not change plasma adenosine concentrations significantly. These results show that citalopram may lead to QT prolongation by stimulating adenosine $A_{1}$ receptors without affecting the release of adenosine.

Therefore, aim of this study was to investigate the efficacy of adenosine receptor antagonists in ameliorating the cardiovascular toxicity of citalopram in rats.

\section{MATERIALS AND METHODS}

This randomized controlled experimental study was performed with male Wistar rats $(\mathrm{n}=21,250-280 \mathrm{~g})$. In this study, all investigators were followed the Guiding Principles in the Care and Use of Laboratory Animals together with the Recommendations from the Declaration of Helsinki. This project was approved by the Dokuz Eylül University Faculty of Medicine Animal Care and Investigational Committee.

\section{Surgical procedure}

Before the experiments, all rats were fasted overnight and allowed free access to water. Rats were anaesthetized by intraperitoneal injection of urethane and chloralose $(500 \mathrm{mg} / \mathrm{kg}$ and $50 \mathrm{mg} / \mathrm{kg}$, respectively, Sigma Chemical, St. Louis, MO,
USA). The trachea was cannulated caudally to the larynx using an 8 gauge nasogastric cannula to allow for spontaneous breathing. The right common carotid artery, left external jugular vein and left femoral vein were cannulated with heparinized polyethylene tubing (PE 50 OD mm [in.] 0.97 [0.038] ID $\mathrm{mm}$ [in.] 0.58 [0.023]). The animal body temperature was kept at $37^{\circ} \mathrm{C}$ during the experiment. All drugs were infused using a perfusor (Perfusor Compact S; Braun, Melsungen, Germany, infusion rate: $0.05 \mathrm{ml} / \mathrm{kg} / \mathrm{min}$ ) on each animal (16).

\section{Outcome parameters}

The MAP was monitored by a pressure transducer (MLT844 Physiological Pressure Transducer; Interlab LTD, Istanbul, Turkey). The data acquisition system (Powerlab / 8SP Data Acquisition System; AD Instruments, Oxford, United Kingdom) was used for recording MAP, HR and electrocardiogram parameters (QRS duration and QT interval) for each rat for 60 minutes. All measurements were performed by a blinded investigator.

\section{Experimental protocol}

After completion of the cannulation procedure, all animals were permitted to stabilize for 15 minutes. Then, rats which had a MAP under $100 \mathrm{mmHg}$ were excluded from the study. Rats were divided into three groups $(\mathrm{n}=7$ each). Before the beginning of the study, sodium cromoglycate $(20 \mathrm{mg} / \mathrm{kg}$, Sigma Chemical, St. Louis, MO, USA) was administered to all rats intravenously to block $\mathrm{A}_{3}$ receptor-mediated hypotensive responses (15). After 3 minutes of sodium cromoglycate pretreatment, citalopram (Fako-Actavis Company, Istanbul, Turkey) toxicity was achieved in all rats with an infusion for 20 minutes (4 $\mathrm{mg} / \mathrm{kg} / \mathrm{min}$ ) (15). Drugs were administered as following:

Group 1 (control, $5 \%$ dextrose, $n=7$ ): Following the citalopram infusion, $5 \%$ dextrose infusion was administred for 60 minutes. To avoid sodium loading with normal saline, we used $5 \%$ dextrose.

Group 2 (DPCPX, n=7): Following the citalopram infusion, $20 \mu \mathrm{g} / \mathrm{kg} / \mathrm{min}$ of DPCPX (Sigma Chemical, St. Louis, MO, USA) infusion was administered for 60 minutes (16).

Group 3 (CSC, n=7): Following the citalopram infusion, 24 $\mu \mathrm{g} / \mathrm{kg} / \mathrm{min}$ of CSC (Sigma Chemical, St. Louis, MO, USA) infusion was administered for 60 minutes (16).

We did not test the effect of DMSO (dimethyl sulfoxide, a vehicle; Aldrich Chemical, St. Louis, MO, USA). In our previous studies, $10 \%$ DMSO did not change the cardiovascular parameters (15).

\section{Drugs}

Urethane $(300 \mathrm{mg} / \mathrm{mL}), \alpha$-chloralose $(40 \mathrm{mg} / \mathrm{mL})$ and sodium cromoglycate $(12 \mathrm{mg} / \mathrm{mL})$ were prepared in distilled 
water. DPCPX $(4 \mathrm{mg} / \mathrm{mL})$ and CSC $(6 \mathrm{mg} / \mathrm{mL})$ were prepared in $10 \%$ DMSO.

\section{Statistical analysis}

We used percent changes in the MAP, HR, QRS duration and QT interval for the statistical analysis. Data were assessed by repeated measures of ANOVA followed by Tukey's multiple comparison tests for within-group comparisons. ANOVA and Tukey's multiple comparison tests were also used to analyze the differences among groups (Graph Pad Instat ${ }^{\mathrm{TM}}$, 1990- 1994, GraphPad Software V2.05a 9342; San Diego, CA, USA). The presentation of the results shows mean values (mean $\pm \mathrm{SEM}$ ) and $95 \%$ confidence intervals (95\% CIs). $\mathrm{p}<0.05$ was accepted as statistically significant.

\section{RESULTS}

There were no statistically significant differences among the baseline measurements in the groups for any of the cardiovascular parameters or body weight ( $\mathrm{p}>0.05$, for all parameters).

\section{The effects of sodium cromoglycate on cardiovascular parameters}

After the stabilization period, sodium cromoglycate did not cause any differences in the cardiovascular parameters $(\mathrm{p}>0.05)$ in the dextrose, DPCPX and CSC groups. When the effects of sodium cromoglycate on all cardiovascular parameters were assessed, no significant differences were found among groups ( $\mathrm{p}>0.05$, Table 1$)$.

\section{The effects of citalopram on cardiovascular parameters}

In all experimental groups, the citalopram infusion decreased MAP $(p<0.001$, Table 1$)$ and HR $(p<0.001$, Table 1) significantly and prolonged the QT interval $(\mathrm{p}<0.01$, Table 1$)$. However, it did not cause any significant changes in the QRS duration ( $p>0.05$, Table 1) in the dextrose, DPCPX and CSC groups. When the effects of the citalopram on MAP, HR, QRS duration and QT interval were compared, no significant differences were found among groups ( $p>0.05$, Figure 1-4).

\section{The effects of dextrose and selective adenosine} receptor antagonists on cardiovascular changes induced by citalopram

In the control group, dextrose infusion after citalopram infusion significantly increased the MAP and HR after 10 minutes (for MAP; $p<0.05$ and for HR; $\mathrm{p}<0.001$, for all minutes, respectively), but it did not have a significant effect on the QRS duration or QT interval ( $\mathrm{p}>0.05$, Table 1).

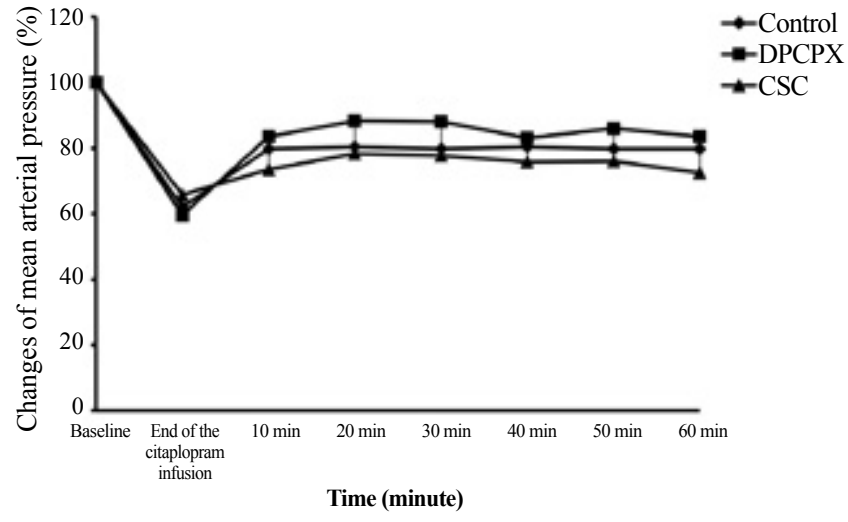

FIG. 1. The effects of dextrose and adenosine receptor antagonists on mean arterial pressure (MAP) after citalopram infusion among groups DPCPX: 8-cyclopentyl-1, 3-dipropylxanthine, a specific adenosine $A_{1}$ receptor antagonist; CSC: (8-(3-chlorostyryl) caffeine; selective adenosine $A_{2 a}$ receptor antagonist

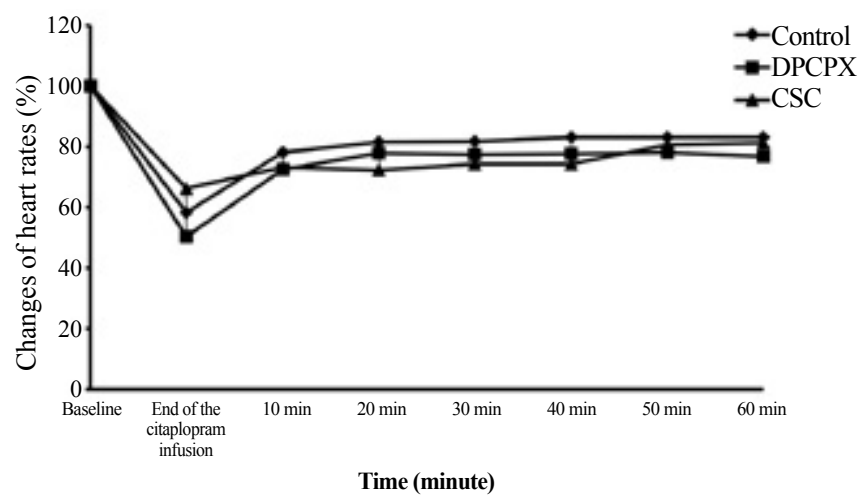

FIG. 2. The effects of dextrose and adenosine receptor antagonists on heart rate $(\mathrm{HR})$ after citalopram infusion among groups DPCPX: 8-cyclopentyl-1, 3-dipropylxanthine, a specific adenosine $A_{1}$ receptor antagonist; CSC: (8-(3-chlorostyryl) caffeine; selective adenosine $A_{2 a}$ receptor antagonist

In the DPCPX group, DPCPX infusion after citalopram administration increased MAP after 10 minutes $(p<0.01)$ and increased HR after 10 minutes ( $<<0.01$ ), but it did not have a significant effect on QRS duration ( $\mathrm{p}>0.05)$. It shortened the QT interval significantly at $30,40,50$, and 60 minutes $(\mathrm{p}<0.05$, Table 1).

In the CSC group, CSC infusion after citalopram infusion did not have a significant effect on the MAP, HR or QRS duration ( $p>0.05$ ). It shortened the QT interval significantly only at 60 minutes $(\mathrm{p}<0.05$, Table 1$)$.

All rats in the experimental groups survived the experiment.

\section{A comparison of the cardiovascular effects among groups}

The infusion of DPCPX after citalopram infusion did not improve the MAP or HR, and also prolonged QRS duration 
TABLE 1. The effects of dextrose and adenosine receptor antagonists on cardiovascular parameters after citalopram infusion within groups

\begin{tabular}{|c|c|c|c|c|c|c|c|c|c|}
\hline & Baseline & $\begin{array}{c}\text { Sodium } \\
\text { cromoglycate }\end{array}$ & $\begin{array}{l}\text { Citalopram } \\
\text { infusion } \\
\text { (20 minutes) }\end{array}$ & $\begin{array}{c}10 \\
\text { minutes }\end{array}$ & $\begin{array}{c}20 \\
\text { minutes }\end{array}$ & $\begin{array}{c}30 \\
\text { minutes }\end{array}$ & $\begin{array}{c}40 \\
\text { minutes }\end{array}$ & $\begin{array}{c}50 \\
\text { minutes }\end{array}$ & $\begin{array}{c}60 \\
\text { minutes }\end{array}$ \\
\hline \multicolumn{10}{|l|}{ MAP (mmHg) } \\
\hline Group 1 (Control) & $115.6 \pm 3.3$ & $115.0 \pm 4.9$ & $72.0 \pm 4.1^{\text {aa }}$ & $92.1 \pm 4.6 \mathrm{~b}$ & $92.9 \pm 4.4 \mathrm{bb}$ & $92.3 \pm 4.8 \mathrm{~b}$ & $93.0 \pm 4.4 \mathrm{bb}$ & $92.3 \pm 3.8^{\mathrm{b}}$ & $92.2 \pm 3.1^{\mathrm{b}}$ \\
\hline Group 2 (DPCPX) & $112.5 \pm 3.3$ & $113.0 \pm 6.1$ & $66.3 \pm 4.3^{\text {aa }}$ & $93.8 \pm 4.6^{\mathrm{bb}}$ & $99.1 \pm 5.0^{\mathrm{bbb}}$ & $98.9 \pm 6.2^{\mathrm{bbb}}$ & $93.3 \pm 8.9^{\mathrm{bb}}$ & $97.2 \pm 6.7^{\mathrm{bb}}$ & $94.2 \pm 9.1^{\mathrm{bb}}$ \\
\hline Group 3 (CSC) & $108.9 \pm 3.8$ & $116.0 \pm 4.4$ & $71.5 \pm 5.6^{\text {aa }}$ & $80.2 \pm 7.8$ & $85.5 \pm 9.7$ & $85.1 \pm 10.1$ & $83.3 \pm 10.4$ & $83.7 \pm 11.3$ & $80.1 \pm 10.5$ \\
\hline \multicolumn{10}{|l|}{ HR (bpm) } \\
\hline Group 1 (Control) & $390.1 \pm 12.1$ & $366.3 \pm 13.9$ & $228.9 \pm 25.9^{\text {aa }}$ & $305.0 \pm 13.6^{\mathrm{bbb}}$ & $317.7 \pm 12.9^{\mathrm{bbb}}$ & $319.0 \pm 13.9^{\mathrm{bbb}}$ & $324.4 \pm 12.9^{\mathrm{bbb}}$ & $324.4 \pm 13.1^{\mathrm{bbb}}$ & $324.4 \pm 13.8^{\mathrm{bbb}}$ \\
\hline Group 2 (DPCPX) & $377.7 \pm 12.4$ & $351.7 \pm 12.3$ & $189.9 \pm 25.0^{\mathrm{aa}}$ & $271.9 \pm 13.0^{\mathrm{bb}}$ & $293.3 \pm 15.2^{\mathrm{bbb}}$ & $292.0 \pm 19.2^{\mathrm{bbb}}$ & $293.1 \pm 19.4^{\text {bbb }}$ & $294.6 \pm 17.8^{\mathrm{bbb}}$ & $289.9 \pm 19.2^{\mathrm{bbb}}$ \\
\hline Group 3 (CSC) & $383.6 \pm 5.5$ & $368.4 \pm 7.9$ & $254.1 \pm 29.8^{\text {aa }}$ & $279.7 \pm 13.9$ & $277.4 \pm 20.6$ & $284.1 \pm 19.2$ & $284.6 \pm 20.2$ & $308.3 \pm 6.1$ & $311.1 \pm 11.6$ \\
\hline \multicolumn{10}{|l|}{ QRS (ms) } \\
\hline Group 1 (Control) & $22.9 \pm 2.2$ & $22.9 \pm 2.3$ & $23.8 \pm 1.7$ & $24.3 \pm 1.9$ & $23.1 \pm 1.9$ & $23.1 \pm 2.2$ & $22.9 \pm 2.2$ & $23.7 \pm 2.4$ & $24.9 \pm 2.8$ \\
\hline Group 2 (DPCPX) & $25.3 \pm 0.8$ & $25.1 \pm 0.5$ & $26.6 \pm 1.4$ & $26.7 \pm 0.9$ & $26.5 \pm 1.0$ & $25.8 \pm 0.8$ & $25.8 \pm 0.7$ & $25.6 \pm 0.8$ & $25.6 \pm 0.6$ \\
\hline Group 3 (CSC) & $25.5 \pm 0.6$ & $26.3 \pm 0.6$ & $27.7 \pm 0.8$ & $26.8 \pm 0.9$ & $26.6 \pm 0.4$ & $26.2 \pm 0.6$ & $26.6 \pm 0.7$ & $25.8 \pm 0.6$ & $25.4 \pm 0.8$ \\
\hline \multicolumn{10}{|l|}{ QT (ms) } \\
\hline Group 1 (Control) & $44.6 \pm 1.3$ & $44.4 \pm 1.2$ & $64.5 \pm 1.6^{\text {aa }}$ & $62.6 \pm 2.9$ & $59.7 \pm 3.3$ & $58.3 \pm 3.8$ & $62.8 \pm 2.4$ & $64.3 \pm 3.2$ & $63.2 \pm 3.8$ \\
\hline Group 2 (DPCPX) & $47.9 \pm 2.6$ & $46.7 \pm 2.9$ & $63.8 \pm 1.1^{\mathrm{a}}$ & $62.3 \pm 3.4$ & $61.4 \pm 2.6$ & $49.9 \pm 3.7^{\mathrm{b}}$ & $50.1 \pm 3.8^{\mathrm{b}}$ & $48.2 \pm 2.7^{\mathrm{b}}$ & $44.3 \pm 1.0^{\mathrm{bbb}}$ \\
\hline Group 3 (CSC) & $44.5 \pm 0.9$ & $46.6 \pm 0.9$ & $65.2 \pm 1.0^{\text {aa }}$ & $64.9 \pm 1.0$ & $59.3 \pm 3.9$ & $55.9 \pm 4.4$ & $55.7 \pm 4.2$ & $53.1 \pm 3.8$ & $52.0 \pm 3.0^{\mathrm{b}}$ \\
\hline
\end{tabular}

MAP: mean arterial pressure; HR: heart rate; ms: milisecond; DPCPX: 8-cyclopentyl-1, 3-dipropylxanthine, a specific adenosine $\mathrm{A}_{1}$ receptor antagonist; CSC: 8-(3-chlorostyryl) caffeine; selective adenosine $\mathrm{A}$, receptor antagonist

a: $\mathrm{p}<0.01 ;$ aa: $\mathrm{p}<0.001$; significance versus the baseline value

b: $\mathrm{p}<0.05 ;$ bb: $\mathrm{p}<0.01 ;$ bbb: $\mathrm{p}<0.001$; significance versus the baseline at the end of citalopram infusion

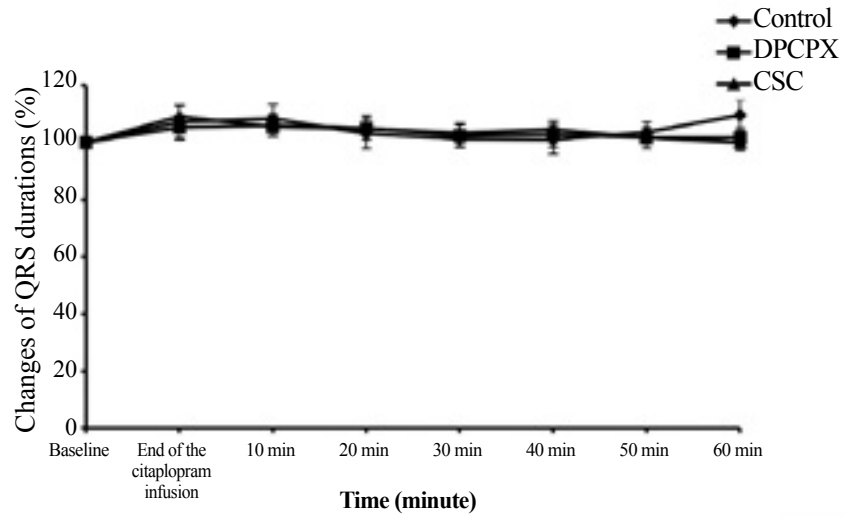

FIG. 3. The effects of dextrose and adenosine receptor antagonists on QRS duration after citalopram infusion among groups

DPCPX: 8-cyclopentyl-1, 3-dipropylxanthine, a specific adenosine $A^{1}$ receptor antagonist; CSC: (8-(3-chlorostyryl) caffeine; selective adenosine $A_{2 a}$ receptor antagonist

significantly when compared to the control group ( $p>0.05$, Figure 1-3). DPCPX infusion shortened the prolongation of the QT interval induced by citalopram infusion at 40,50 and 60 minutes $(105.5 \pm 8.6 \%, 140.9 \pm 4.0 \%, 95 \%$ CI 10.13 to 60.70 , $\mathrm{p}<0.01$, at 40 minutes; $102.5 \pm 7.8 \%, 143.8 \pm 3.3 \%, 95 \% \mathrm{CI}$ $16.35-66.10, \mathrm{p}<0.01$, at 50 minutes; $94.2 \pm 5.4 \%, 141.0 \pm 4.8 \%$, $95 \%$ CI 25.62 to $68.07, \mathrm{p}<0.001$, at 60 minutes; Figure 4) compared to dextrose infusion.

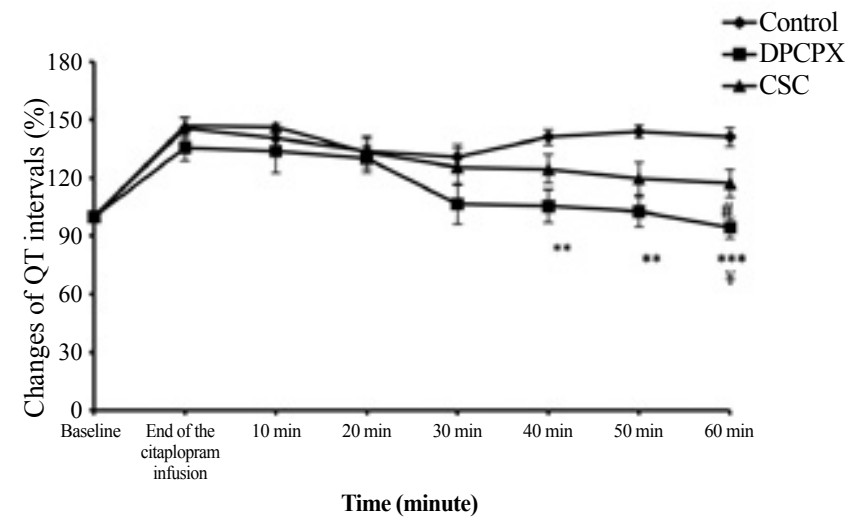

FIG. 4. The effects of dextrose and adenosine receptor antagonists on the QT interval after citalopram infusion among groups

${ }^{* *} p<0.01,{ }^{* * *} p<0.01$; DPCPX versus control group

${ }^{*} \mathrm{p}<0.05$; CSC versus control group

${ }^{*} p<0.05$;

DPCPX: 8-cyclopentyl-13-dipropylxanthine, a specific adenosine $A_{1}$ receptor antagonist; CSC: (8-(3-chlorostyryl) caffeine; selective adenosine $A_{2 a}$ receptor antagonist

After citalopram infusion, CSC did not improve the MAP or $\mathrm{HR}$, and also prolonged the QRS duration significantly when compared to the control group ( $>>0.05$, Figure 1-3). CSC infusion shortened the prolongation of the QT interval induced by citalopram infusion at 60 minutes $(117.1 \pm 7.2 \%, 141.0 \pm 4.8 \%$, 
$95 \%$ CI 2.662 to $45.11, \mathrm{p}<0.05$, Figure 4 ) compared to dextrose infusion.

DPCPX infusion shortened the prolongation of the QT interval induced by citalopram infusion at 60 minutes $(94.2 \pm 5.4 \%$, $117.1 \pm 7.2 \%, 95 \%$ CI -44.18 to $-1.734, p<0.05$, Figure 4 ) compared to CSC infusion.

\section{DISCUSSION}

In our toxicity model, citalopram infusion significantly decreased MAP and HR and also prolonged the QT interval, but there was no significant difference in the QRS duration in all groups. After citalopram administration, adenosine A1 receptor inhibition with DPCPX shortened the prolongation of the QT interval at 40, 50 and 60 minutes, and adenosine $\mathrm{A}_{2 \mathrm{a}}$ receptor inhibition with CSC shortened the QT interval at 60 minutes when compared to dextrose administration. Furthermore, when we evaluated the improvement QT interval prolongation with DPCPX or CSC administration, DPCPX was shortened significantly the QT interval prolongation at 60 minutes.

Citalopram overdose can cause life-threatening cardiotoxicity. In a recent meta-analysis, there was a statistically significant association between an increase in the QTc interval and using SSRIs; additionally citalopram, is associated with QTc prolongation more than most other SSRIs. $(3,4)$. In a normal ventricle, repolarization occurs via the cardiac rapid delayed rectifier current, IKr. Drug-induced QT interval prolongation and torsades de pointes are associated with the inhibition of cardiac potassium $(\mathrm{K}+)$ channel proteins encoded by the human ether-a-go-go related gene (hERG) (4). In cellular electrophysiological studies, it has been shown that citalopram has a high degree of potential to inhibit the $\mathrm{K}^{+}$current which is responsible for the action potential repolarization phase in the heart; the prolongation of the QTc interval induced by a toxic dose of citalopram is associated with this condition. Also, it has been shown that citalopram causes a prolongation in action potential time, a prolongation of the QTc interval, as well as an increase in torsade de pointes risk and sudden death by inhibiting G-protein activated inward rectifier potassium channels (GIRK) and hERG potassium channels (17-22).

In the cardiac system, activation of adenosine A1 receptors by adenosine produces negative chronotropic, dromotropic and inotropic effects. Adenosine A1 receptor-mediated action exists in two types: one involves indirect or anti-adrenergic effects (cAMP-dependent) and the other involves direct effects (cAMP-independent). In the indirect pathway, adenosine antagonizes the action of $\beta$-adrenergic agonists. Adenosine produces anti-adrenergic activities over delayed rectifier potassium currents (IK). The inhibition of catecholamine-related
IK currents prolongs the action potential. In the direct pathway, the activation of $\mathrm{K}+$ channels by adenosine causes the hyperpolarization of sinoatrial (SA) node cells, shortening of the action potential of atrial cells and depressing the action potential of atrioventricular nodal cells (23-25).

In our study, 5\% dextrose and DPCPX infusions significantly reversed citalopram-induced reductions in MAP and HR. CSC infusion did not cause a significant change in MAP or HR. In an isolated atrium study, it was found that the adenosine $\mathrm{A}_{2}$ receptor antagonist (DMPX; 3.7 dimethyl-1- dipropargylxanthine) did not prevent citalopram-induced negative inotropic and chronotropic effects, but DPCPX and theophylline (a non-selective adenosine $A_{1} / A_{2}$ receptor antagonist) blocked these effects. The effects of citalopram have been explained by adenosine re-uptake inhibition or by activation of $A_{1}$ receptors in this study (14). In our previous study, it was found that administration of DPCPX and CSC before citalopram infusion did not prevent citalopram-induced reductions in MAP and HR (15). Our results suggest that DPCPX improves citalopram-induced hypotension and bradycardia through eliminating the negative inotropic and chronotropic effects of endogenous adenosine via adenosine $\mathrm{A}_{1}$ receptors. The correction of MAP and HR with 5\% dextrose can be explained since SSRIs do not cause treatment-resistant hypotension like TCAs $(16,22)$, and SSRIs are safer than TCAs because of their low cardiotoxic, anticholinergic and antihistaminergic side effects and their low risk of hypotension (22). The 5\% dextrose infusion may have corrected the hemodynamic parameters by increasing the intravascular volume.

In our study, the prolongation of the QT interval induced by citalopram was shortened significantly by DPCPX (after 30 minutes) and by CSC (after 60 minutes). In our previous study, Oransay et al. demonstrated that CSC administration before citalopram infusion did not prevent the prolongation of the QT interval. However, DPCPX administration before citalopram infusion significantly prevented the prolongation of the QT interval. Researchers have shown that a toxic dose of citalopram does not increase plasma adenosine levels but rather potentiates the cardiovascular effects of endogenous adenosine (15). Our results support the notion that adenosine $\mathrm{A}_{1}$ receptor stimulation can play a role in the mechanism of QT interval prolongation, and are compatible with our previous study.

In conclusion, the reversal of citalopram-induced QT interval prolongation by DPCPX indicates that adenosine $\mathrm{A}_{1}$ receptor stimulation may play a role in the pathophysiology of cardiovascular toxicity induced by citalopram. Selective adenosine $\mathrm{A}_{1}$ receptor antagonists can be used as an antidote to reverse citalopram-induced QT interval prolongation. Regarding the mechanism of citalopram-induced QT interval prolongation, inhibition of $\mathrm{IKr}$ currents by adenosine $\mathrm{A}_{1}$ stimulation 
most likely plays a role. Further studies are needed to investigate the role of potassium channels in adenosine-mediated citalopram toxicity.

Ethics Committee Approval: Ethics committee approval was received for this study from the ethics committee Dokuz Eylül University Faculty of Medicine Animal Care and Investigational Committee (Protocol Number: 65/2009).

\section{Informed Consent: N/A.}

Peer-review: Externally peer-reviewed.

Author contributions: Concept - Ş.K., M.B.; Design - Ş.K., M.B.; Supervision - Ş.K.; Resource - Ş.K.; Materials - M.B., N.H., K.O., S.K.; Data Collection \&/or Processing - M.B., N.H., K.O., Ş.K.; Analysis \&/or Interpretation - M.B., N.H., K.O., Ş.K.; Literature Search - Ş.K., M.B.; Writing - Ş.K., M.B.; Critical Reviews M.B., N.H., K.O., Ş.K., Y.T.

Conflict of Interest: No conflict of interest was declared by the authors.

Financial Disclosure: The authors declared that this study has received no financial support.

\section{REFERENCES}

1. DRUGDEX®System: Klasco RK (Ed): DRUGDEX® System. Truven Health Analytics, Greenwood Village, Colorado, Vol. 162 expires 12/2014.

2. Cooke MJ, Waring WS. Citalopram and cardiac toxicity. Eur $J$ Clin Pharmacol 2013;69:755-60. [CrossRef]

3. Beach SR, Kostis WJ, Celano CM, Januzzi JL, Ruskin JN, Noseworthy PA, et. al. Meta-analysis of selective serotonin reuptake inhibitor-associated QTc prolongation. J Clin Psychiatry 2014;75:441-9. [CrossRef]

4. Kogut C, Crouse EB, Vieweg WV, Hasnain M, Baranchuk A, Digby GC, et.al. Selective serotonin reuptake inhibitors and torsade de pointes: new concepts and new directions derived from a systematic review of case reports. Ther Adv Drug Saf 2013;4:189-98. [CrossRef]

5. Liotier J, Coudoré F. Drug monitoring of a case of citalopram overdosage. Drug Chem Toxicol 2011;34:420-3. [CrossRef]

6. Jimmink A, Caminada K, Hunfeld NG, Touw DJ. Clinical toxicology of citalopram after acute intoxication with the sole drug or in combination with other drugs, overview of 26 cases. Ther Drug Monit 2008;30:365-71. [CrossRef]

7. Tarabar AF, Hoffman RS, Lelson LS. Citalopram overdose, late presentation if torsdae de pointes with cardiac arrest. JMed Toxicol 2008;4:101-5. [CrossRef]

8. Isbister GK, Bowe SJ, Dawson A, Whyte IM. Relative toxicity of selective serotonin reuptake inhibitors (SSRIs) in overdose. $J$ Toxicol Clin Toxicol 2004;42:277-85. [CrossRef]

9. Lynge J, Hellsten Y. Distribution of adenosine A1, A2A and A2B receptors in human skeletal muscle. Acta Physiol Scand 2000;169:283-90. [CrossRef]

10. Yan L, Burbiel JC, Maas A, Muller CE. Adenosine receptor agonists: from basic medicinal chemistry to clinical development. Expert Opin Emerg Drugs 2003;8:537-76. [CrossRef]

11. Olsson RA, Pearson JD. Cardiovascular purinoceptors. Physiol Rev 1990;70:761-45.

12. Belardinelli L, Shryock JC, Snowdy S, Zhang Y, Monopoli A, Lozza $\mathrm{G}$, et al. The A2a adenosine receptor mediates coronary vasodilation. J Pharmacol Exp Ther 1998;284:1066-73.

13. Pousti A, Deemyad T, Malihi G. Mechanism of inhibitory effect of citalopram on isolated guinea-pig atria in relation to adenosine receptor. Hum Psychopharmacol 2004;19:347-50. [CrossRef]

14. Oransay K, Hocaoglu N, Buyukdeligoz M, Tuncok Y, Kalkan $\mathrm{S}$. The role of adenosine receptors and endogenous adenosine in citalopram-induced cardiovascular toxicity. Indian J Pharmacol 2014;46:378-85. [CrossRef]

15. Kalkan S, Aygoren O, Akgun A, Gidener S, Guven H, Tuncok Y. Do adenosine receptors play a role in amitriptyline-induced cardiovascular toxicity in rats. $J$ Toxicol Clin Toxicol 2004;42:94554. [CrossRef]

16. Kobayashi T, Washiyama K, Ikeda K. Inhibition of G proteinactivated inwardly rectifying $\mathrm{K}+$ channels by various antidepressant drugs. Neuropsychopharmacology 2004;29:1841-51. [CrossRef]

17. Perrin MJ, Subbiah RN, Vandenberg JI, Hill AP. Human ether-ago-go related gene (hERG) $\mathrm{K}+$ channels: function and dysfunction. Prog Biophys Mol Biol 2008;98:137-48. [CrossRef]

18. Jo SH1, Youm JB, Lee CO, Earm YE, Ho WK. Blockade of the HERG human cardiac $\mathrm{K}(+)$ channel by the antidepressant drug amitriptyline. Br J Pharmacol 2000;129:1474-80. [CrossRef]

19. Pacher P, Kecskemeti V. Cardiovascular Side Effects of New Antidepressants and Antipsychotics: New Drugs, old Concerns? Curr Pharm Des 2004;10:2463-75. [CrossRef]

20. Witchel HJ1, Pabbathi VK, Hofmann G, Paul AA, Hancox JC. Inhibitor actions of the selective serotonin re-uptake inhibitor citalopram on HERG and ventricular L-type calcium currents. FEBS Lett 2002;512:59-66. [CrossRef]

21. Gintant G. An evaluation of hERG current assay performance, Translating preclinical safety studies to clinical QT prolongation. Pharmacol Ther 2011;129:109-19. [CrossRef]

22. Belardinelli L, Shryock JC, Song Y, Wang D, Srinivas M. Ionic basis of electrophysiological actions of adenosine on cardiomyocytes. FASEB J 1995;9:359-65.

23. Lerman BB, Belardinelli L. Cardiac electrophysiology of adenosine. Basic and clinical concepts. Circulation 1991;83:1499509. [CrossRef]

24. Shen WK, Kurachi Y. Mechanisms of adenosine-mediated actions on cellular and clinical cardiac electrophysiology. Mayo Clin Proc 1995;70:274-91.[CrossRef] 